\title{
In vivo toxicity and antioxidant of pressurize hot water Phyllanthus tenellus Roxb. extracts
}

Swee Keong Yeap ${ }^{1}$, Chean Yeah Yong ${ }^{2}$, Umar Faruq ${ }^{2}$, Hui Kian Ong ${ }^{2}$, Zahiah binti Mohamed Amin², Wan Yong $\mathrm{Ho}^{3}$, Shaiful Sharifudin ${ }^{4}$ and Indu Bala Jaganath ${ }^{5^{*}}$

\begin{abstract}
Background: Phyllanthus tenellus Roxb. has been traditionally used to treat inflammation and liver diseases and its medicinal property may be due to the presence of relatively high levels of hydrosable tannins. Recent report revealed that pressurized hot water extraction of $P$. tenellus significantly increased the concentration of hydrolysable tannins and its catabolites. Thus, this study was aimed to evaluate the in vivo toxicity and antioxidant capacity of pressurized hot water extraction of $P$. tenellus on healthy mice.

Methods: Pressurized hot water extraction $P$. tenellus was carried out and standardized to $7.9 \%$ hydrosable tannins. In vitro toxicity of the extract was tested on NIH 3 T3 cell by MTT assay. The cellular antioxidant level was quantified by measuring cellular level of glutathione. Oral sub-chronic toxicity $(200,1000$ and $3000 \mathrm{mg} / \mathrm{kg}$ body weight) of $P$. tenellus extract were evaluated on healthy mice. Liver and kidney antioxidant level was quantified by measuring levels of Ferric Reducing Antioxidant Potential (FRAP), superoxide dismutase, glutathione.
\end{abstract}

Results: The $P$. tenellus extract did not induce cytotoxicity on murine NIH 3 T3 cells up to $200 \mu \mathrm{g} / \mathrm{mL}$ for $48 \mathrm{~h}$. Besides, level of glutathione was higher in the extract treated NIH 3 T3 cells. P. tenellus extract did not cause mortality at all tested concentration. When treated with $1000 \mathrm{mg} / \mathrm{kg}$ of the extract, serum liver enzymes (ALP and ALT) and LDH were lower than normal control and mice treated with $200 \mathrm{mg} / \mathrm{kg}$ of extract. Moreover, SOD, FRAP and glutathione levels of liver of the mice treated with 200 and $1000 \mathrm{mg} / \mathrm{kg}$ of extract were higher than the normal control mice. On the other hand, when treated with $3000 \mathrm{mg} / \mathrm{kg}$ of extract, serum liver enzymes (ALP and ALT) and LDH were higher than normal mice without changing the liver SOD and glutathione level, which may contribute to the histological sign of ballooning hepatocyte.

Conclusion: $P$. tenellus extract standardized with $7.9 \%$ hydrosable tannins and their catabolites increased the antioxidant levels while reducing the nitric oxide levels in both liver and kidney without causing any acute and sub-chronic toxicity in the mice.

Keywords: Pressurized, Phyllanthus tenellus, Hydrosable tannin, Toxicity, Antioxidant, Nitric oxide

\footnotetext{
* Correspondence: indu@mardi.gov.my

${ }^{5}$ Strategic Planning \& Innovation Management Centre, Malaysian Agricultural

Research and Development Institute (MARDI), 43400 Serdang, Selangor,

Malaysia

Full list of author information is available at the end of the article
}

(c) The Author(s). 2021 Open Access This article is licensed under a Creative Commons Attribution 4.0 International License, which permits use, sharing, adaptation, distribution and reproduction in any medium or format, as long as you give appropriate credit to the original author(s) and the source, provide a link to the Creative Commons licence, and indicate if changes were made. The images or other third party material in this article are included in the article's Creative Commons licence, unless indicated otherwise in a credit line to the material. If material is not included in the article's Creative Commons licence and your intended use is not permitted by statutory regulation or exceeds the permitted use, you will need to obtain permission directly from the copyright holder. To view a copy of this licence, visit http://creativecommons.org/licenses/by/4.0/ The Creative Commons Public Domain Dedication waiver (http://creativecommons.org/publicdomain/zero/1.0/) applies to the data made available in this article, unless otherwise stated in a credit line to the data. 


\section{Background}

The genus Phyllanthus, containing more than 700 species, is commonly used in traditional herbal remedies and is widely distributed throughout Asia and South America [1, 2]. In India, Phyllanthus has been used as a diuretic and for its antibacterial, antioxidant and immunomodulator properties [3]. Phyllanthus tenellus is less common compared to its close relative $P$. niruri and $P$. amarus but is considered an important species especially in the Brazilian tropical and sub-tropical regions. $P$. tenellus has been reported to contain tannins and ellagitannins [1], which is believed to contribute to its antihepatitis virus activity $[4,5]$, UV protection [6] and immunomodulatory effects [7]. P. tenellus extract was reported with in vitro $[3,8]$ antioxidant activity, which has contributed to its in vitro hepatoprotective effect [3]. In vivo study performed by Lee et al. [9] has supported the above findings where $P$. tenellus extract was able to strengthen the liver reduced glutathione peroxidase (GSH-Px) to promote recovery of carbon tetrachloride induced liver damage. Besides, P. tenellus extract was also reported with anti-inflammatory effect [7]. In addition, investigation have also revealed the antimicrobial activity of $P$. tenellus in comparison to other species of Phyllanthus [2]. Moreover, in vivo study has reported that $P$. tenellus exhibit potent analgesic effect against neurogenic and inflammatory pain $[10,11]$. Unlike its more common relatives $P$. niruri and $P$. amarus, the bioactivities and safety studies of $P$. tenellus has been not well documented [12].

As the use of herbal medicines is expanding rapidly as alternative treatments worldwide, scientist have to ensure its safety through carrying out precise toxicity studies $[2,13]$. Ethanol extract of aerial part of $P$. tenellus was previously reported with no toxic effect up to $2.5 \mathrm{~g} /$ $\mathrm{kg}$ body weight. Although $P$. tenellus ethanolic extract did not cause mortality up to $2.5 \mathrm{~g} / \mathrm{kg}$ body weight, the treated rat was observed to have depressant behavior at this dosage [2]. This effect was correlated with the prolyl oligopeptidase and acetylcholinesterase inhibition by the corilagin present in the P. tenellus extract [14]. Our previous study has indicated that by modifying the extraction method and by just using pressurized water at $121^{\circ} \mathrm{C}$, we managed to significantly increase the concentration of bioactive metabolites particularly the hydrosable tannins, that believed to be Urolithin A that catabolized from ellagic acid [15] compared to previous report [1]. Besides, corilagin that was reported to cause depression [14] was not detected in the pressurized water extract [15]. As the chemical profile of this extract differs considerably from the previous report, there is a need to carry out safety and efficacy studies of the newly formulated $P$. tenellus. This study was therefore performed to evaluate the sub-chronic toxicity of $P$. tenellus extract. In addition, the antioxidant effect of the extract on healthy animals were also quantified in this study. Identification of the toxicity and antioxidant effect of the $P$. tenellus extract at the tested dosages help to select the range of concentration that suitable for the future in vivo bioactivities study.

\section{Methods}

\section{Preparation of $P$. tenellus extract}

The wild $P$. tenellus plant was sourced from Cameron Highlands, Malaysia, identified and verified by the taxonomist, Dr. Salmah Idris, from Malaysia Agricultural Research and Development Institute (MARDI). The plant has been deposited at MARDI's herbarium under the botanical voucher (MD10525). Pressurized hot water extract of Phyllanthus tenellus was prepared according to the previous study. The extract utilized in this study was quantified by LC-MS.MS to standardize the concentration of the hydrosable tannins at approximate $8 \%$ [15]. P. tenellus extract was diluted in RPMI-1640 medium and distilled water at $1 \mathrm{~g} / \mathrm{mL}$ for in vitro and in vivo assays, respectively.

\section{In vitro cytotoxicity and level of GSH of $P$. tenellus extract treated NIH 3 T3 cells}

NIH 3 T3 (CRL-1658) was obtained from ATCC, USA and maintained in RPMI-1640 medium supplemented with $10 \%$ fetal bovine serum in $5 \% \mathrm{CO}_{2}$ incubator. For the cytotoxicity test, $8 \times 10^{5}$ cells $/ \mathrm{mL}$ of NIH $3 \mathrm{~T} 3$ cells was seeded in 96 well plate overnight. On the next day, the seeded cells were treated with serial diluted $P$. tenellus extract $(200,100,50,25,12.5,6.25,3.12 \mu \mathrm{g} / \mathrm{mL})$ for $48 \mathrm{~h}$. After the incubation period, each well was added with $20 \mu \mathrm{L}$ of MTT solution. After $4 \mathrm{~h}$ of incubation, the supernatants were removed and the purple formazan crystal formed was dissolved with $100 \mu \mathrm{L}$ dimethyl sulfoxide. The absorbance of the sample was measured at $570 \mathrm{~nm}$ using Quant ELISA plate reader (Bio-tek Instruments, USA). Percentage of viability of the extract treated cells was calculated by the absorbance ratio between extract treated cells with the untreated control cells multiplied by $100 \%$.

For the quantification of GSH, NIH 3 T3 cells were treated with 200,100 , and $50 \mu \mathrm{g} / \mathrm{mL}$. After $48 \mathrm{~h}$ of treatment, cells were collected and subjected repeated cycle of freezing by liquid nitrogen and thawing at $37^{\circ} \mathrm{C}$. Then, cell lysate was collected after centrifuging the cells extract at $13,000 \mathrm{rpm}$ for $15 \mathrm{~min}$ at $4{ }^{\circ} \mathrm{C}$. The GSH content was quantified by glutathione assay kit (Sigma-Aldrich, USA).

\section{Animal}

This study was approved by the Animal Ethics Committee (AEC), Malaysian Agricultural Research and 
Development Institute (Approval no 20160902/R/ MAEC00001) and compliance to the guidelines of the AEC, MARDI. Female BALB/c mice $(n=36 ; 6$ weeks old) were purchased from animal house, Institute of Bioscience, Universiti Putra Malaysia. Mice ( $n=3$ per cage) were house in plastic cage and supplied with distilled water and standard pellets 702p (Gold Coin, Malaysia) ad libitum under $12 \mathrm{~h}$ of light/dark cycles per day with temperature $\sim 22-24{ }^{\circ} \mathrm{C}$ and $\sim 70 \%$ of humidity.

\section{Sub-chronic toxicity test}

Sub-chronic toxicity test was designed and performed as previously reported [9]. After acclimatization, mice were randomly assigned into 4 groups ( $n=9$ per group). The control group received daily oral feeding of distilled water $(200 \mu \mathrm{L})$ while Phyllanthus treated groups received daily oral treatments with 200, 1000 and $3000 \mathrm{mg} / \mathrm{kg}$ of P. tenellus extract dissolved in the distilled water for 28 days. Water and standard food pellets were provided ad libitum throughout the experimental period. After 28 days, weight of the mice was recorded. All mice were anesthetized with $2 \%$ isoflurane (1,349,014, Merck, USA) and sacrificed by cervical dislocation [16].. Serum, kidney, liver and spleen were collected and subjected to the following assays.

\section{Serum biochemical analysis}

Level of serum liver enzyme markers aspartate aminotransferase (AST), alanine aminotransferase (ALT), alkaline phosphatase (ALP), creatinine and Lactic acid dehydrogenase (LDH) were quantified by Hitachi 902 Automatic Analyzer (Hitachi, Japan) using reagents from Roche (Germany).

\section{Liver and kidney antioxidant and nitric oxide quantification}

Liver and kidney were collected from each mouse, washed with phosphate buffer saline (PBS) (Sigma-Aldrich, USA), weighed and meshed by $0.2 \mu \mathrm{m}$ cell strainer (SPL Life Sciences, China) in cold PBS to obtain liver and kidney homogenate. The homogenate was subjected to ferric-reducing ability plasma (FRAP), superoxide dismutase (SOD), malondialdehyde (MDA) and nitric oxide (NO) quantification were based on the previously reported methods [17]. The GSH content was quantified by glutathione assay kit (Sigma-Aldrich, USA).

\section{Statistical analysis}

Means and standard deviation from nine mice per groups (each with three technical replicates) were calculated. Significant differences $(p<0.05)$ between the normal and $P$. tenellus extract treated groups for all experiments were analyzed using one-way analysis of variance (ANOVA) followed by post-hoc Duncan analysis using SPSS version 20.

\section{Results}

In vitro cytotoxicity and glutathione level of $P$. tenellus extract

P. tenellus extract did not reduce viability of NIH 3 T3 cells up to $200 \mu \mathrm{g} / \mathrm{mL}$ (Fig. 1a). For the viability assay, 200 and $100 \mu \mathrm{g} / \mathrm{mL}$ of the extract increased $10 \%$ of viability of the NIH 3 T3 cells comparing to the untreated group. Besides, 200 and $100 \mu \mathrm{g} / \mathrm{mL}$ of the extract also enhanced 1.5 and 1.3 folds of cellular GSH in NIH 3 T3 cells comparing to the untreated group (Fig. 1b).

\section{In vivo toxicity of $P$. tenellus extract}

In this study, mice were orally fed with 200, 1000 and $3000 \mathrm{mg} / \mathrm{kg}$ body weight of pressurized hot water extract of $P$. tenellus for 28 days. Throughout the treatment period, all $P$. tenellus extract treated mice survived without showing any sign and symptoms of toxicity (Results not shown). In addition, no significant changes were observed for the final body weight, fasting glucose and organ/body weight ratio after 28 days of $P$. tenellus extract treatment (Table 1).

\section{$P$. tenellus extract influenced serum biochemical markers and liver histology}

Comparing to the normal control, $1000 \mathrm{mg} / \mathrm{kg}$ body weight of $P$. tenellus extract significantly $(p<0.05)$ reduced the serum ALP, ALT, LDH and creatinine levels, ie 0.85 folds, 0.98 folds and 0.91 folds compared to the control mice (Fig. 2a, b and c). On the other hand, 3000 $\mathrm{mg} / \mathrm{kg}$ body weight of the extract was recorded with 1.23 folds, 1.53 folds and 1.2 folds of serum ALP, AST and LDH level (Fig. 2a and b) than the control mice. Unlike the serum liver enzyme, no significant changes of serum level of creatinine in the mice treated with 3000 $\mathrm{mg} / \mathrm{kg}$ body weight of $P$. tenellus extract were observed compared to the untreated normal control mice (Fig. 2c). This result was supported by the histological assessment where ballooning was observed in the liver section of mice treated with $3000 \mathrm{mg} / \mathrm{kg}$ body weight of $P$. tenellus extract (Fig. 3a) without significant changes were observed in the kidney section (Fig. 3b). Moreover, no histological changes were observed in the liver and kidney section of mice treated with 200 and $1000 \mathrm{mg} / \mathrm{kg}$ body weight of $P$. tenellus extract.

\section{P. tenellus extract enhanced the liver and kidney antioxidant level}

P. tenellus extract $(1000 \mathrm{mg} / \mathrm{kg}$ body weight) enhanced the 1.8 folds, 1.6 folds, 1.7 folds of liver.

SOD, GSH and FRAP antioxidant levels when compared to the normal control mice. Besides, this 


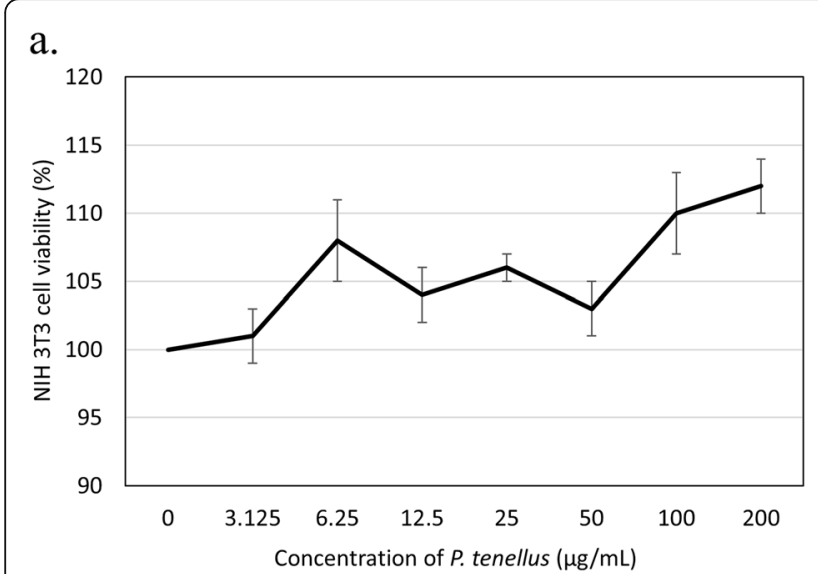

b.

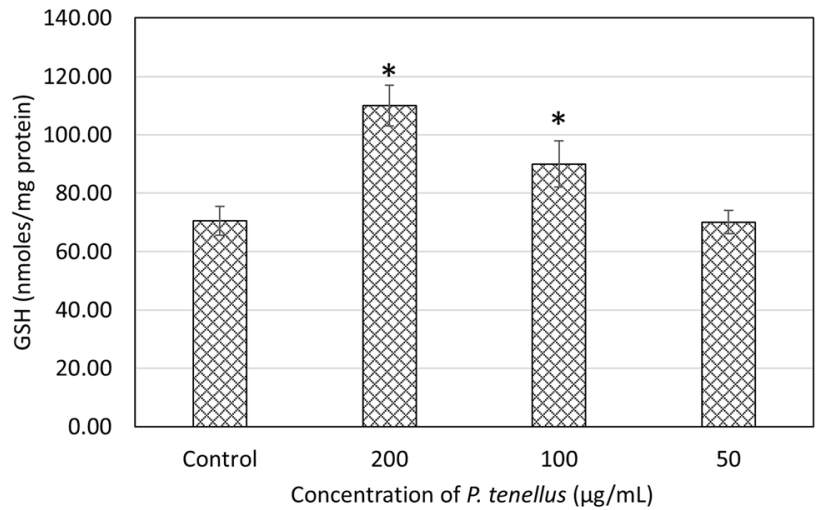

Fig. 1 a Viability of NIH 3 T3 cells treated with P. tenellus extract $(200,100,50,25,12.5,6.25,3.12 \mu \mathrm{g} / \mathrm{mL})$ for $48 \mathrm{~h}$ b GSH content of NIH 3 T3 cells treated with $P$. tenellus extract $(200,100$ and $50 \mu \mathrm{g} / \mathrm{mL})$ for $48 \mathrm{~h}$

treatment also enhanced 1.48 folds, 1.17 folds and 1.24 folds of kidney SOD, GSH and FRAP antioxidant levels comparing to the normal control mice (Fig. 4a, b and c). In addition, MDA lipid peroxidation and $\mathrm{NO}$ level in the liver of mice treated with $1000 \mathrm{mg} / \mathrm{kg}$ body weight of $P$. tenellus extract were lower, ie 0.58 folds and 0.63 folds as compared to the normal control mice (Fig. $5 \mathrm{a}$ and $\mathrm{b}$ ). Similar pattern was observed in the kidney of mice treated with $1000 \mathrm{mg} / \mathrm{kg}$ of extract, which recorded with 0.83 folds and 0.73 folds of MDA lipid peroxidation and NO level of the control mice (Fig. 5a and b). On the other hand, mice treated with $3000 \mathrm{mg} / \mathrm{kg}$ body weight of $P$. tenellus extract was reported with significantly 1.5 folds higher $(p<0.05)$ FRAP levels in the liver (Fig. 4b). In contrary with the lower dosage, highest concentration of $P$. tenellus extract was found with significantly 1.26 folds highest NO level in the liver (Fig. 5b).

\section{Discussion}

Phyllanthus species have been widely used as a traditional medicine to treat urolithiasis, inflammation, diabetes and hepatitis. In comparison to other more popular Phyllanthus species, P. tenellus has not been exposed to elaborate scientific studies especially with respect to its bioactivity and toxicity studies [2]. In this previous study, a preliminary short-term acute toxicity study was performed and reported that up to 2500 $\mathrm{mg} / \mathrm{kg}$ body weight of $P$. tenellus ethanol extract did not induce mortality in mice. However, slight agitation was observed in the mice treated with the highest dosage of the extract [2]. Similarly, in the present study, no cytotoxic effect was observed in NIH $3 \mathrm{~T} 3$ cells cultured with $200 \mu \mathrm{g} / \mathrm{mL}$ of the extract in vitro. In addition, no mortality was observed in this subchronic toxicity study of $P$. tenellus extract for all the tested concentrations. In addition, no significant changes of body weight and organ weight when comparing between normal control and $P$. tenellus extract treated mice were observed. These results indicate that $P$. tenellus extract did not induce sub-chronic toxicity up to $3000 \mathrm{mg} / \mathrm{kg}$ body weight. To further evaluate the effect of $P$. tenellus on liver and kidney,

Table 1 Body weight (day 0 and day 28) and organ weight of control and Phyllanthus treated mice in sub-chronic toxicity study

\begin{tabular}{lllll}
\hline & Control & Phyllanthus 200 & Phyllanthus 1000 & Phyllanthus 3000 \\
\hline Day 0 BW (g) & $19.85 \pm 1.80$ & $20.18 \pm 1.60$ & $19.89 \pm 1.80$ & $20.21 \pm 1.40$ \\
Day 28 BW (g) & $22.25 \pm 2.20$ & $22.33 \pm 1.90$ & $22.57 \pm 1.70$ & $22.14 \pm 2.10$ \\
Fasting glucose (mmol/L) & $5.21 \pm 0.21$ & $5.32 \pm 0.44$ & $5.17 \pm 0.62$ & $5.20 \pm 0.32$ \\
Brain/BW ratio & $0.014 \pm 0.002$ & $0.015 \pm 0.003$ & $0.014 \pm 0.001$ & $0.016 \pm 0.002$ \\
Heart/BW ratio & $0.006 \pm 0.001$ & $0.006 \pm 0.001$ & $0.005 \pm 0.001$ & $0.005 \pm 0.001$ \\
Lung/BW ratio & $0.008 \pm 0.001$ & $0.008 \pm 0.001$ & $0.008 \pm 0.001$ & $0.008 \pm 0.001$ \\
Liver/BW ratio & $0.061 \pm 0.018$ & $0.056 \pm 0.013$ & $0.046 \pm 0.021$ & $0.047 \pm 0.008$ \\
Kidney/BW ratio & $0.019 \pm 0.010$ & $0.017 \pm 0.009$ & $0.015 \pm 0.013$ & $0.016 \pm 0.011$ \\
Spleen/BW ratio & $0.005 \pm 0.001$ & $0.005 \pm 0.001$ & $0.004 \pm 0.001$ & $0.004 \pm 0.001$ \\
\hline
\end{tabular}



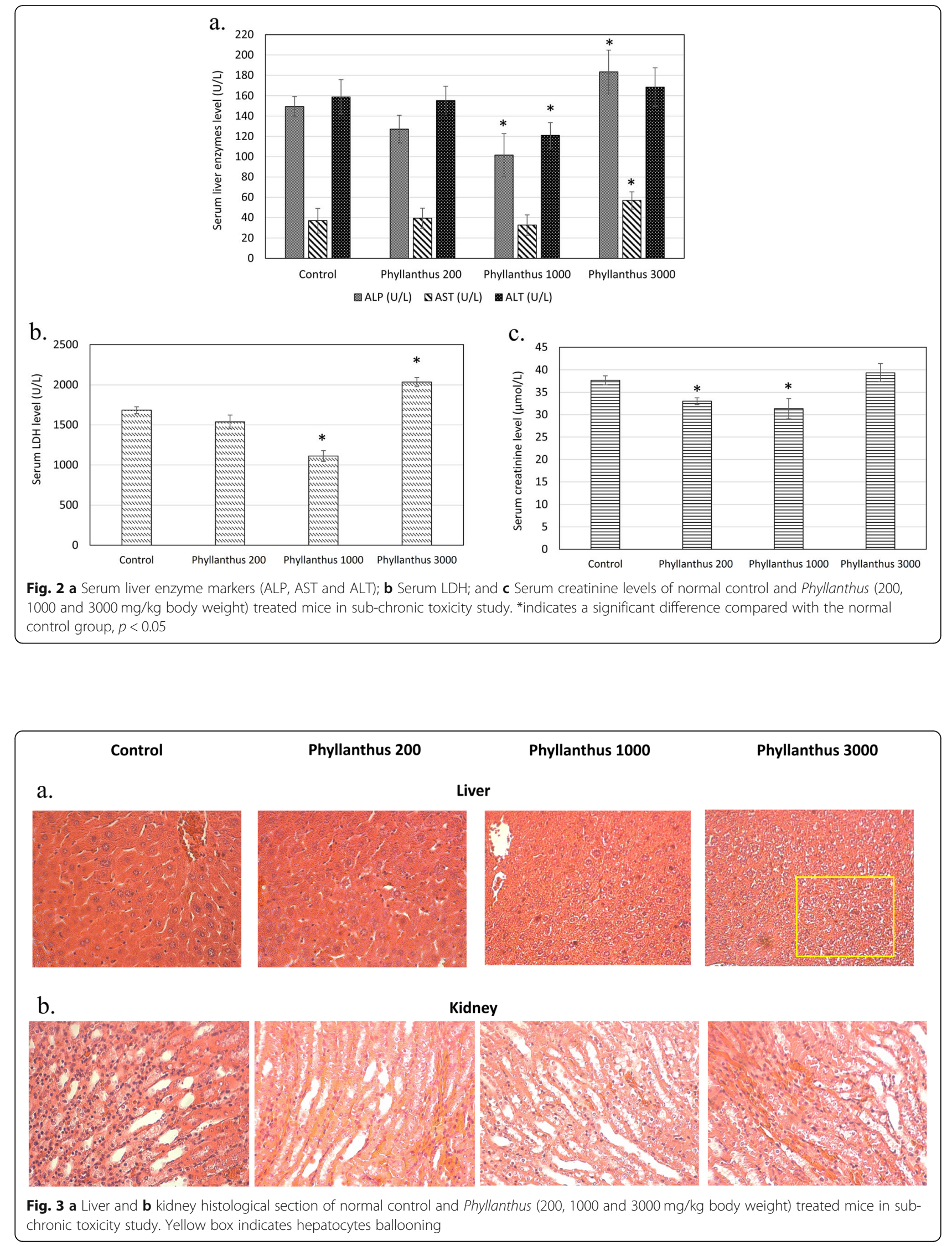

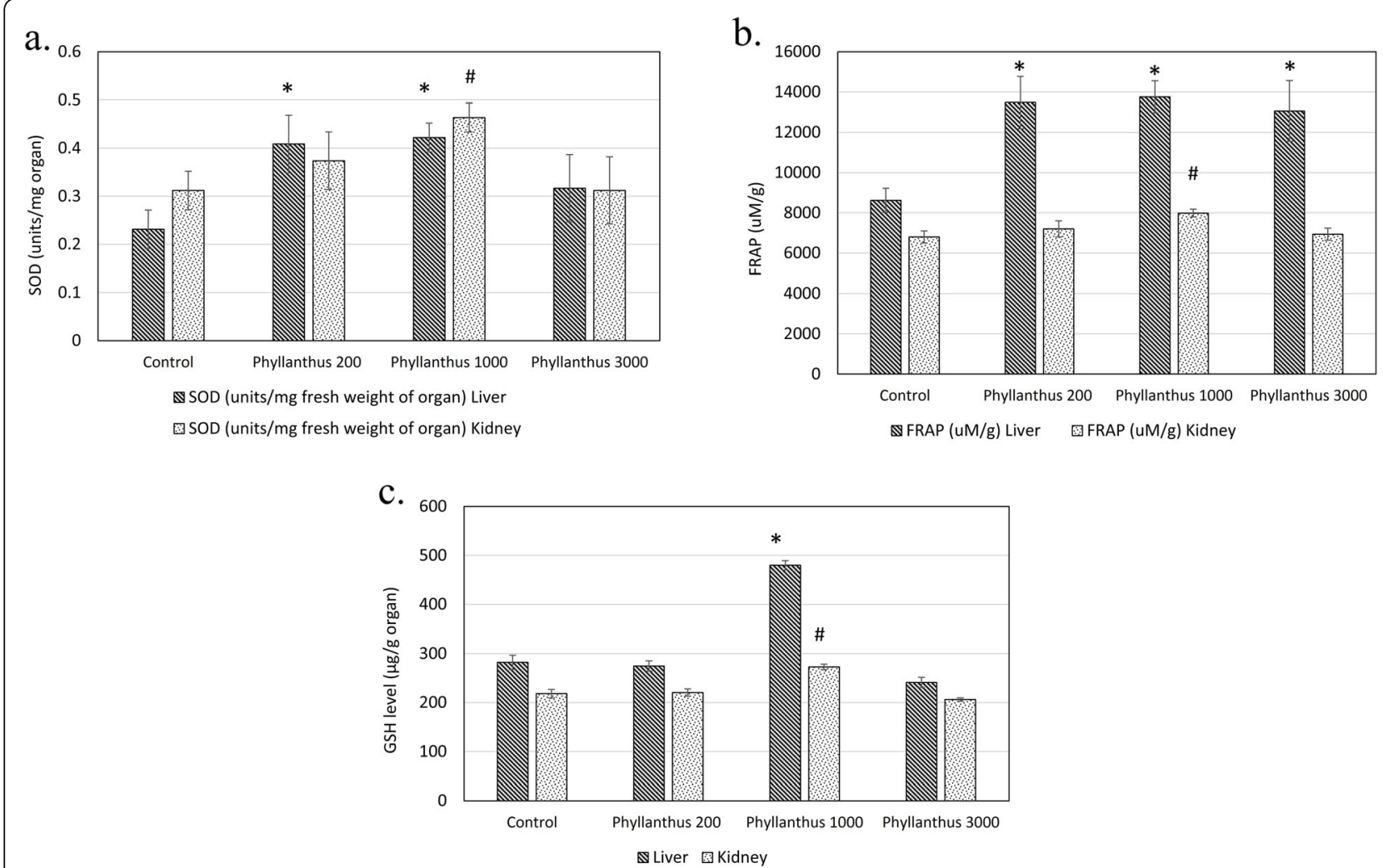

Fig. 4 a SOD; b FRAP and c GSH level of liver and kidney of normal control and Phyllanthus (200, 1000 and $3000 \mathrm{mg} / \mathrm{kg}$ body weight) treated mice in sub-chronic toxicity study. ${ }^{*}$ indicates a significant difference compared with the normal control group, $p<0.05$

organ histological sections and serum biochemical markers were analyzed. At low dose of P. tenellus extract, no significant differences in the serum liver enzyme level compared to the normal control was observed. However, when the mice were treated with $1000 \mathrm{mg} / \mathrm{kg}$ body of $P$. tenellus extract, lower levels of serum liver enzyme and creatinine without any alterations of the liver and kidney histological sections were observed. This result reveal that a treatment of up to $1000 \mathrm{mg} / \mathrm{kg}$ body weight of extract on mice is considered safe as it did not cause any observable side effects to the liver and the kidney.

P. tenellus has been traditionally used for hepatitis [2]. Study by Srirama et al. [3] reported that methanolic
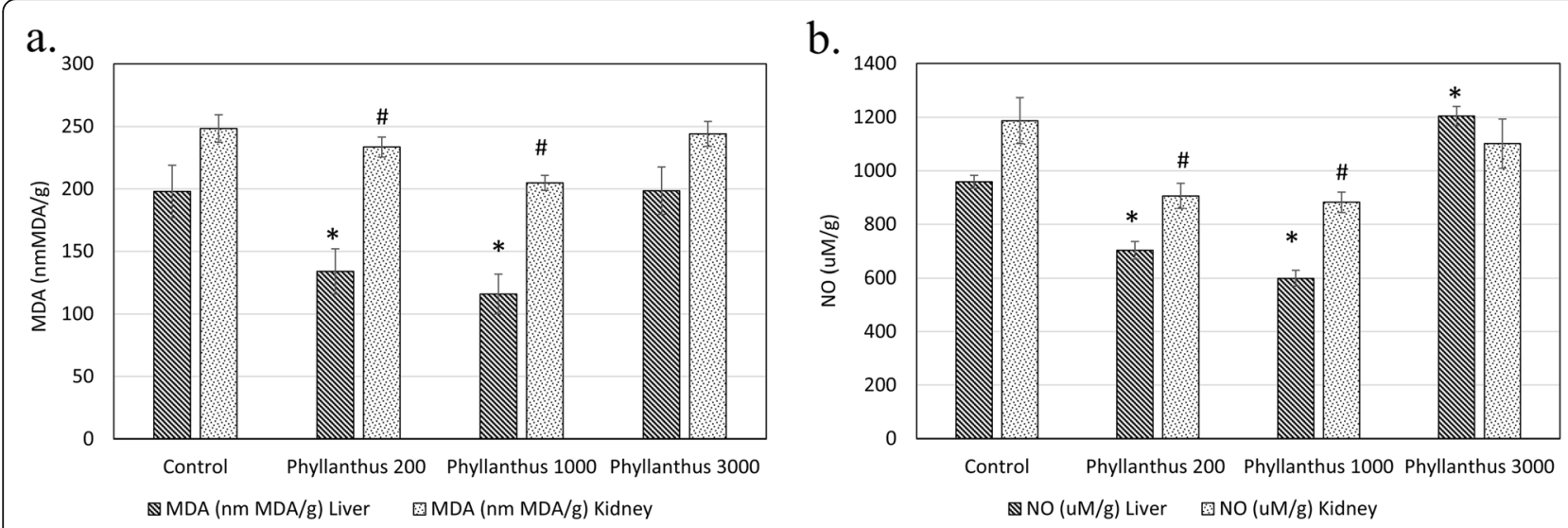

Fig. 5 a MDA lipid peroxidation and $\mathbf{b}$ NO level of liver and kidney of normal control and Phyllanthus (200, 1000 and 3000 mg/kg body weight) treated mice in sub-chronic toxicity study. ${ }^{*}$ indicates a significant difference compared with the normal control group, $p<0.05$ 
extract of P. tenellus did not possess any in vitro hepatoprotective effect in contradiction to our results. In addition, the results of this study revealed that the hepatoprotective effect of $P$. tenellus could possibly be dose dependent. The highest concentration of $P$. tenellus extract (3000 $\mathrm{mg} / \mathrm{kg}$ body weight) was observed with hepatocyte ballooning and increased serum liver enzyme markers. These results tend to support the finding of the acute toxicity study in the previous investigation [2]. With regard to this, consumption of high dosages of $P$. tenellus should be avoided regardless of it not causing mortality and morbidity of the treated mice.

Earlier phytochemical study on $P$. tenellus indicated that this plant contains high polyphenol and hydrosable tannin content [15], which are related to various bioactivities including antioxidant, antimicrobial [18] and immunomodulatory effects [19]. Similar effects are observed in this study where NIH 3 T3 cells treated with $P$. tenellus extract was observed with higher level of cellular GSH. Besides, mice treated with $1000 \mathrm{mg} / \mathrm{kg}$ body weight of $P$. tenellus extract exhibited higher levels of invivo antioxidant (FRAP, SOD and GSH) and were associated with lower levels of lipid peroxidation and nitric oxide accumulation both, in the liver and the kidney. The antioxidant activity is hypothesized to be attributed by the presence of hydrosable tannin particularly the catabolized ellagic acid (presumed to be Urolithin A) that has been detected in abundance and was the key compound in the extract [15]. Urolithin A is a bioactive secondary metabolite of complex ellagic acid [20]. Urolithin A has been reported to possess in vitro and in vivo antioxidant activity, thereby contributing to the protection of several reactive oxygen species (ROS) induced stress such as survival of neuronal cells under oxidative stress [21]. However, availability of Urolithin A is very much dependent on the presence of a specific intestinal microbe species from the Eggerthellaceae family which catabolizes ellagic acid to Urolithin A [20]. Pressurized hot water extraction was able to catabolize the ellagic acid to a metabolite believed to be Urolithin A in P. tenellus [15]. We believe that 'Urolithin A' may be one of the main contributors to the high in vivo antioxidant effect observed as this metabolite was detected in significantly high concentration compared to other metabolites [15].

In addition, intake of 200 and $1000 \mathrm{mg} / \mathrm{kg}$ body weight of the extract was also observed with lower levels of NO, which maybe attributed by the immunosuppression effect of Urolithin A [22]. On the other hand, a high dose of $3000 \mathrm{mg} / \mathrm{kg}$ of the extract was associated with significantly higher level of NO in the liver. Accumulation of NO may induce cellular stress to hepatocytes [23], and contribute to alteration of liver histological structure and serum liver enzyme levels. The mild hepatitis effect of high dosage of $P$. tenellus extract could be due to the high concentration of total tannin, similar to the in vivo adverse effects of high concentration of tannin containing Mimosa pudica root extract [24].

\section{Conclusions}

The oral sub-chronic toxicity study of $P$. tenellus extract revealed that $1000 \mathrm{mg} / \mathrm{kg}$ body weight of the extract did not exhibit any toxic side effects. On the other hand, it enhanced the antioxidant levels in both the liver and kidney while suppressing the accumulation of NO. Although the $3000 \mathrm{mg} / \mathrm{kg}$ body weight of $P$. tenellus extract did not cause mortality or morbidity, mild toxicity was observed based on the preliminary findings of significant increase in serum liver enzymes associated with the accumulation of liver nitric oxide and hepatocytes ballooning degeneration. In short, pressurized hot water extraction of $P$. tenellus extract particularly at $1000 \mathrm{mg} /$ $\mathrm{kg}$ has the potential to become an important therapeutic agent due to its high antioxidant capacity and NO- suppressing activity. However, more preclinical studies of the toxicity and bioactivities evaluation with the use of immunohistochemistry markers on the isolated hydrosable tannin particularly the Urolithin A are needed to validate the functions and the potential side effect of the hydrosable tannin in the $P$. tenellus extract.

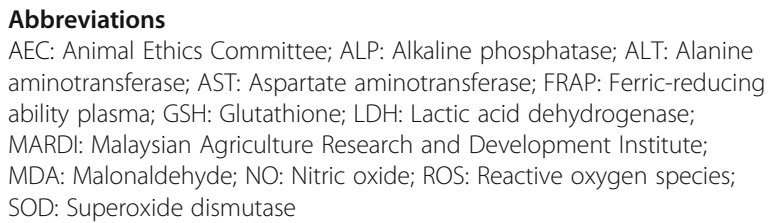

Acknowledgements

Not Applicable.

\section{Authors' contributions}

SKY, IBJ designed the experiment; IBJ profiled and standardised the extract; CYY, UF, HKO, ZMA, WYH, SS performed the experiment; SKY, CYY, WYH, SS and IBJ analysed the results. SKY, WYH, CYY and IBJ prepared the manuscript. All authors have gone through and approved the manuscript. All authors have agreed both to be personally accountable for the author's own contributions and to ensure that questions related to the accuracy or integrity of any part of the work.

\section{Funding}

We thank Malaysian Agriculture Research and Development Institute (MARDI) for funding this project under the special program. This research was funded by Malaysian Agriculture Research and Development Institute (MARDI), Grant Number TP-RB-0055 under special project. The funder has no role in the design of the study; collection, analysis, and interpretation of data; and in writing the manuscript.

Availability of data and materials

The datasets used and/or analysed during the current study are available from the corresponding author on reasonable request.

\section{Declarations}

Ethics approval and consent to participate

This work was approved by Animal Ethics Committee (AEC), MARDI (no 20160902/R/MAEC00001) and was performed in accordance with the Guide 
for the Care and Use of Laboratory Animals prepared by the Animal Ethics Committee (AEC), MARDI (Malaysia).

\section{Consent for publication}

Not applicable.

\section{Competing interests}

Wan Yong Ho is the Associate Editor of BMC Complementary and Alternative Medicine. All authors in this article declare no conflict of interest.

\section{Author details}

${ }^{1}$ China-ASEAN College of Marine Sciences, Xiamen University Malaysia, 43900 Sepang, Selangor, Malaysia. ${ }^{2}$ Institute of Bioscience, Universiti Putra Malaysia, 43400 Serdang, Selangor, Malaysia. ${ }^{3}$ Faculty of Science, University of Nottingham Malaysia, Jalan Broga, 43500 Semenyih, Selangor, Malaysia. ${ }^{4}$ Biotechnology Research Centre, Malaysian Agricultural Research and Development Institute (MARDI), 43400 Serdang, Selangor, Malaysia. ${ }^{5}$ Strategic Planning \& Innovation Management Centre, Malaysian Agricultural Research and Development Institute (MARDI), 43400 Serdang, Selangor, Malaysia.

Received: 16 January 2020 Accepted: 23 February 2021

Published online: 09 March 2021

\section{References}

1. Qi W, Hua L, Gao K. Chemical constituents of the plants from the genus Phyllanthus. Chem Biodivers. 2014;11:364-95.

2. Silva TCL, Filho JV, Amorim ELC, Souza IA, Albuquerque UP, Araujo EC. Acute toxicity study of stone-breaker. Rev Cienc Farm Basica Apl. 2012;33: 205-10.

3. Srirama R, Deepak HB, Senthilkumar U, Ravikanth G, Gurumurthy BR, Shivanna MB, Chandrasekaran CV, Agarwal A, Shaanker RU. Hepatoprotective activity of Indian Phyllanthus. Pharm Biol. 2012:50:948-53.

4. Huang RL, Huang YL, Ou JC, Chen CC, Hsu FL, Chang C. Screening of 25 compounds isolated from Phyllanthus species for anti-human hepatitis B virus in vitro. Phytother Res. 2003;17:449-53.

5. Shead A, Vickery K, Pajkos A, Medhurst R, Freiman J, Dixon R, Cossart Y. Effect of Phyllanthus plant extracts on duck hepatitis $B$ virus in vitro and in vivo. Antivir Res. 1992;18:127-38.

6. Victorio CP, Leal-Costa MV, Schwartz Tavares E, MacHado Kuster R, Salgueiro Lage CL. Effects of supplemental UV-A on the development, anatomy and metabolite production of Phyllanthus tenellus cultured in vitro. Photochem Photobiol. 2011;87:685-9.

7. Ignacio SRN, Ferreira JLP, Almeida MB, Kubelka CF. Nitric oxide production by murine peritoneal macrophages in vitro and in vivo treated with Phyllanthus tenellus extracts. J Ethnopharmacol. 2001;74:181-7.

8. Sampath Kumara KK, Chethan J, Manasa N, Ashadevi JS, Prakash HS. Bioactive potential of herbaceous Phyllanthus species. Int J Pharm Pharm Sci. 2012:4:457-61.

9. Lee CY, Peng WH, Cheng HY, Chen FN, Lai MT, Chiu TH. Hepatoprotective effect of Phyllanthus in Taiwan on acute liver damage induced by carbon tetrachloride. Am J Chin Med. 2006;34:471-82.

10. Santos ARS, Filho VC, Niero R, Viana AM, Moreno FN, Campos MM, Yunes RA, Calixto JB. Analgesic effect of callus culture extracts from selected species of Phyllanthus in mice. J Pharm Pharmacol. 1994;46:755-9.

11. Santos ARS, Filho VC, Yunes RA, Calixto JB. Further studies on the antinociceptive action of the hydroalcoholic extracts from plants of the genus, Phyllanthus. J Pharm Pharmacol. 1995;47:66-71.

12. Mao X, Wu LF, Guo HL, Chen WJ, Cui YP, Oi O, Li S, Liang WY, Yang GH, Shao YY, Zhu D, She GM, You Y, Zhang LZ. The genus Phyllanthus: an ethnopharmacological, phytochemical, and pharmacological review. Evid Based Complement Alternat Med. 2016;2016:7584952.

13. Ekor M. The growing use of herbal medicines: issues relating to adverse reactions and challenges in monitoring safety. Front Pharmacol. 2013;4:177.

14. Dos Santos MZ, de Avila J, Morel A, Canto-Dorow TS, Mostardeiro MA, Dalcol II. Evaluation of prolyl oligopeptidase and acetylcholinesterase inhibition by Phyllanthus tenellus Roxb. from Brazil. Nat Prod Res 2019; in press.

15. Jusoh NHM, Subki A, Yeap SK, Yap KC, Jaganath IB. Pressurized hot water extraction of hydrosable tannins from Phyllanthus tenellus Roxb. BMC Chem. 2019;13:134
16. Zulkawi N, Ng KH, Zamberi R, Yeap SK, Satharasinghe D, Jaganath IB, Jamaluddin AB, Tan SW, Ho WY, Alitheen NB, Long K. In vitro characterization and in vivo toxicity, antioxidant and immunomodulatory effect of fermented foods. Xeniji BMC Complement Altern Med. 2017;17:344.

17. Yusof HM, Ali N, Yeap SK, Ho WY, Beh BK, Koh SP, Long K, Abdul Aziz S, Alitheen NB. Hepatoprotective effect of fermented soybean (nutrient enriched soybean tempeh) against alcohol-induced liver damage in mice. Evid Based Complement Alternat Med. 2013;2013:274274.

18. Reddy MK, Gupta SK, Jacob MR, Khan SI, Ferreira D. Antioxidant, antimalarial and antimicrobial activities of tannin-rich fractions, ellagitannins and phenolic acids from Punica granatum L. Planta Med. 2007:73:461-7.

19. Okuda T, Yoshida T, Hatano T, Ito H. Ellagitannins renewed the concept of tannins. In: Chemistry and biology of ellagitannins: An underestimated class of bioactive plant polyphenols; 2009. p. 1-54.

20. Selma MV, Beltran D, Luna MC, Romo-Vaquero M, Garcia-Villalba R, Mira A Espin JC, Tomas-Barberan FA. Isolation of human intestinal bacteria capable of producing the bioactive metabolite isourolithin a from ellagic acid. Front Microbiol. 2017:8:1521

21. Espin JC, Larrosa M, Garcia-Conesa MT, Tomas-Barberan F. Biological significance of urolithins, the gut microbial ellagic acid-derived metabolites: the evidence so far. Evidance-Based Complementary and Alternative Medicine. 2013:2013:270418.

22. Zhang S, Al-Maghout T, Cao H, Pelzl L, Salker MS, Veldhoen M, Cheng A Lang F, Singh Y. Gut bacterial metabolite urolithin a (UA) mitigates $\mathrm{Ca}^{2+}$ entry in T cells by regulating miR-10a-5p. Front Immunol. 2019;10:1737.

23. Horras CJ, Lamb CL, Mitchell KA. Regulation of hepatocyte fate by interferon- $\gamma$. Cytokine Growth Factor Rev. 2011;22:35-43.

24. Vejayan J, Jamunaa A, Halijah I, Ambu S. Adverse effects of tannin contained in Mimosa pudica root extract. J Appl Sci Sci Res. 2016;16:477-83.

\section{Publisher's Note}

Springer Nature remains neutral with regard to jurisdictional claims in published maps and institutional affiliations.

\section{Ready to submit your research? Choose BMC and benefit from:}

- fast, convenient online submission

- thorough peer review by experienced researchers in your field

- rapid publication on acceptance

- support for research data, including large and complex data types

- gold Open Access which fosters wider collaboration and increased citations

- maximum visibility for your research: over 100M website views per year

At $\mathrm{BMC}$, research is always in progress.

Learn more biomedcentral.com/submissions 